\title{
Comparing Determinants of Poverty and Hunger among Small Holder Farms of adopters and Non- Adopters of Conservation Technologies in Ghana
}

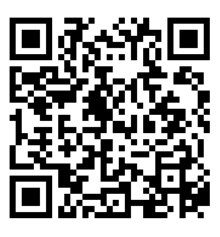

\author{
Fariya Abubakari* and Farida Abubakari \\ Department of Agricultural Economics, Department of Crop and Soil Sciences, Kwame Nkrumah University of Science and Technology, Ghana
}

Submission: December 12, 2016; Published: January 16, 2017

*Corresponding author: Fariya Abubakari, Department of Agricultural Economics, Agribusiness and Extension, Kwame Nkrumah University of Science and Technology, Ghana, Email: fariyaabubakari@yahoo.com

\begin{abstract}
Poverty is a state or condition of having little or no money, goods or means of support whiles hunger on the other hand is the painful sensation or state of weakness caused by the need for food. This study examines the determinants of poverty and hunger among smallholder farmers. The focus was on adopters and non-adopters of conservation methods in Talensi Nabdam District of Upper East Region of Ghana. Seven communities were purposively selected from Talensi Nabdam District and 50 farmers were randomly selected from the seven communities namely; Belungu, Kongo, Damolgo, Zalerigu, Dagliga, Nangodi, and Arigu. Data collected using the questionnaire include gender, marital status, age, extension contact, access to credit, education, awareness of conservation methods, training, labor, farmer based organisation and household size. Log it model was used to estimate the determinants of poverty and hunger among smallholder farmers who adopted or did not adopt conservation methods. Independent samples t-test was used to compare the output of adopters and non-adopters of stone bunds, earth bunds, vertiver grass, manure, local grass, wood logs, tree planting, drainage trench and ploughing across slope in the study areas. Adopters of stone bunds had higher output of rice than non-adopters, adopters of earth bunds had low output of rice than non-adopters, adopters of vertiver grass had low output of rice than non-adopters and adopters of manure had high output of rice than non-adopters. The study concluded that all the variables have negative and significant effect on poverty and hunger whiles age; gender and marital status have positive and significant effect on poverty and hunger and household size was not significant.
\end{abstract}

Keywords: Determinants; Poverty; Hunger; Adopters; Non-adopter

\section{Introduction}

The 2000/2001 World Development Report, which defines poverty as "pronounced deprivation in well-being", groups the dimensions of poverty as Opportunity (access to markets, resources and income generating opportunities), Empowerment (influence on the state institutions and participation in political processes and local decision making) and Security (reducing vulnerability to risks such as ill health, economic shocks and natural disasters) Nelson \& Agbey [1].

Although the most recent human poverty index in Ghana indicates that poverty level has declined from 51.7 percent in 1999 to 41 percent in 2003, ISSER [2] many people still lie below the poverty line. Poverty is generally agreed to be complex and multi-dimensional in nature. Its causes are diverse, its manifestations are contextual and it is not only a state of deprivation but also a set of processes Carney [3], World Bank
[4]. In Kankwendas [5] view, povertyis almost never defined in itself but described through other concepts such as growth, well-being, exclusion or equity. As a result, it is not easy to identify the key elements of poverty, especially when defined in relation to specific contexts whether global, regional, national or local Asamoah [6]. International institutions such as the World Bank and the International Monetary Fund (IMF) use economic indices to measure poverty Asamoah [6]. To these institutions, people who earn less than a dollar $(\$ 1.90)$ a day are considered poor World Bank, 2000

In Ghana, the cause of rural poverty has been attributed to low output especially in the agricultural sector, which employs about eighty percent of the economically active rural population ISSER [2]. The low output levels result from many factors including erratic weather, poor farming practices, high costs of inputs, infertile lands and credit as well as poor infrastructural 
development, market and storage facilities Asamoah [6].In order to reduce poverty, many African governments have realized the need to increase production in the agricultural sector. Consequently countries such as Ghana, Cote d'Ivoire and Nigeria have appealed to their international development partners to assist in developing the agricultural sectors of their economies since agriculture, especially small-holder farming contributes to poverty reduction by providing employment, food security and raw materials for majority of the rural and peri-urban population Asamoah [6].

Conservation measures can reduce yield variability in at least two ways. First, conservation can improve moisture retention during low-rainfall periods and thereby reduce moisture stress and enhance plant growth Hengsdijk et al. [7]. Second, conservation technology can mitigate the consequences of flooding and thus can reduce associated crop damage and topsoil run-off during high-rainfall periods Shively [8]. Therefore this study seeks to examine the determinants of poverty and hunger among small-holder farmers of adopters and non-adopters of conservation methods in Talensi Nabdam district of upper east region of Ghana.

\section{Methodology \\ Description of the study area}

Talensi Nabdam District is the youngest district in Upper East Region of Ghana which was carved out from the then Bolgatanga District Assembly. It has its capital at Tongo. Figure 1 below shows the map of Talensi Nabdam District.

\section{Data collection and sampling technique}

Among the eight districts in the region, Talensi Nabdam district was randomly chosen for the study because it is the largest district in Upper East Region; its economy is based on agriculture as well as being noted for serious erosion problem Fariya Abubakari et al. [9]. Seven communities were purposively selected from Talensi Nabdam District and fifty farmers were randomly selected from the seven communities namely;Belungu, Kongo, Damolgo, Zalerigu, Dagliga, Nangodi, and Arigu.Data collected include, gender, marital status, age, extension contact, access to credit, education, awareness of conservation methods, training, labor, farmer based organization and household size by administering questionnaire

\section{Analytical technique}

Log it model was used to estimate the determinants of poverty and hunger among smallholder farmers of adopters and non-adopters techniques like stone bunds, earth bunds, vertiver grass, manure, local grass, wood logs, tree planting, drainage trench and ploughing across slope and the independent samples t-test was used to compare the output of adopters and nonadopters of the conservation methods who were rice farmers in Talensi Nabdam District of Upper East Region of Ghana.

The empirical model used in this study was based on
Adesina \& Zinnah [7] conceptual framework for farmer's adoption decisions. The probability that a farmer adopted soil conservation technology was assumed to be a function of selected variables and unobserved error term. The dependent variable in the log it model was adoption of soil conservation technology. It took the value of 1 if soil conservation technology was adopted.

$$
\begin{aligned}
& Y_{i}^{*}=\sum_{j=1}^{c} \beta_{j} W_{i j}+u \\
& \text { equation } 1
\end{aligned}
$$

Where $\mathrm{i}=1,2,3,4$ and 5, $W_{i j} s$ are the exogenous variables and is the error term. Observed variables are $Y_{i}=1$ when $Y_{i}^{*}>0$ for the $i^{\text {th }}$ farmer. $Y_{i} s$ are binary choices in which $Y_{i}=1$ when decision to adopt soil conservation technology prevail over decision to abandon technology. $\sum \beta_{j} W_{i j}$ is an index function effect of explanatory variables on choice behavior. The $\mathrm{i}^{\text {th }}$ farmer will choose to continue with technology if $u>-\sum \beta_{j} W_{i j}$.

Log it model was used to estimate the determinants of poverty and hunger among smallholder farmers of adopters and non-adopters of conservation methods. The probit model and its specification are shown below and the independent variable used to estimate the coefficients of the adoption model are also defined. The estimated model is expressed as follows:

$Q_{i j}=\beta_{0}+\beta_{1} E d u_{i j}+\beta_{2} A g e_{i j}+\beta_{3} F_{z_{i j}}+\beta_{4} H H_{s_{i j}}+\beta_{5} E X_{i j}+\beta_{6} R E_{i j}+\beta_{7} O W N_{i j}+\beta_{8} S E X_{i j}+\beta_{9} C R E_{i j}+\beta_{10} O R G_{i j}+\mu_{1}$

Where ${ }^{\mathrm{i}}=$ is the household head

$j=$ Soil conservation technology

$j=1,2,3 \ldots \ldots \ldots \ldots \ldots . . n$

$Q=$ Adoption $^{1}$, if farmer has adopted $\mathrm{I},{ }^{0}$ if otherwise

$E D U$ : Educational (number of years of schooling

AGE=Age of the farmer

$\mathrm{HH}_{\mathrm{S}}$ Household size

$\mathrm{TRAI}=$ training $(1$ if farmer received training, 0 if otherwise $)$

EX=Extension (1, if farmer received extension contact in 2011, 0 otherwise)

Sex (1, if male, 0 otherwise)

AWARE $=$ Awareness of conservation methods ( 1 if farmer is aware, 0 if otherwise)

$\mathrm{CRE}=$ Credit $(1$, if farmer access credit in 2011, 0 otherwise)

Lab= Labor (1 if family labor, 0 if otherwise)

Mari= Marital status (1 if married, 0 if otherwise)

$\mathrm{ORG}=$ Farmer's organization $(1$, if farmer is a member of local group, 0 otherwise)

$\mu_{1}=$ Error term capturing unobserved effect

$\beta_{0}=$ Intercept 


\section{Results and Discussion}

\section{Determinants of poverty and hunger log it model estimate}

Table1: Log it Estimates for adopters and non-adopters of conservation methods.

\begin{tabular}{|c|c|c|}
\hline Variable & Coefficient & Z-value \\
\hline Age of respondence & 0.007 & $2.390^{* * *}$ \\
\hline Household size & 0.108 & 0.219 \\
\hline $\begin{array}{c}\text { Gender of } \\
\text { respondence }\end{array}$ & 0.64 & $3.118^{*}$ \\
\hline Marital status & 0.51 & $1.203^{* * *}$ \\
\hline Educational level & -0.37 & $1.055^{* *}$ \\
\hline $\begin{array}{c}\text { Member of farmer } \\
\text { based organization }\end{array}$ & -0.61 & $0.351^{* * *}$ \\
\hline $\begin{array}{c}\text { Type of labor } \\
\text { employed }\end{array}$ & -0.201 & $0.8054^{* * *}$ \\
\hline Access to credit & -0.05 & $1.624^{* * *}$ \\
\hline Extension contact & -0.03 & $1.347^{* *}$ \\
\hline Access to training & -0.031 & $0.912^{* * *}$ \\
\hline Awareness of soil & -0.202 & $0.306^{*}$ \\
\hline conservation & 350 & \\
\hline Observations & 0.601 & \\
\hline Adjusted R-squared & 0.73 & \\
\hline R & & \\
\hline
\end{tabular}

Table 1 below shows the log it estimates on the determinants of poverty and hunger among smallholder farming of adopters and non-adopters of conservation methods in Talensi Nabdam District of Ghana. The value of $\mathrm{R}^{2}(0.73)$ indicates that the model is of good fit and statistically significant.

Gender has a coefficient of 0.64 and is significant at $10 \%$, which means a unit increase in either male or female would increase the poverty level by 3.118.Gender of the household has important impact for agricultural productivities especially in the study area. From the study, about $87 \%$ of the farmers were males and $13 \%$ were females and majority of the active youth were involved in farming. This implies that, their youthfulness and strength did not have any positive impact to increase agricultural productivities. Meanwhile they depend on agriculture for their livelihood; the crops they grow are either consumed or sold to the market hence they were not able to use their strength to adopt effective conservation methods to help control erosion and subsequently increase yield. Therefore, the district would record low yield which could lead to lack of food and subsequently hunger in the district. This contradicts to the findings of Farida \& Fariya [11], found that gender as an important determinant in reducing poverty among tomato farmers in Talensi Nabdam District of Ghana.

Age of the respondence had a coefficient of 0.007 and is significant at one percent, which means a unit increase in years would increase the poverty level by 2.390 .This implies that, the energy available for work decreases with increase in age. This could lead to reduction in cultivable lands as well as income, yield of crops and expose the soil to erosion as the farmers age keeps increasing; they wouldn't be any enough strength to help in adoption of the conservation methods as most of the conservation methods requires more physical and human muscle and this could affect farmers yield and some could record low or no yield after a cropping season. This would negatively affect poverty and subsequently leads to hunger in the district. This contradicts to the findings of Khalid et al. (2005) who reported in their study that, age is an important determinant of poverty and where age of the household head is high; the household is more likely to be non-poor.

Marital status of the household had a coefficient of 0.51 and is significant at one percent, which means a unit increase in marital status would increase poverty by 1.203 .From the study, about $93 \%$ of the household were married and engaged in polygamous marriage. This implies that, as more people get married in the district, their dependency ratio also increase and as it increases, more money is required by household heads to feed their families and about $90 \%$ of the household depend on agriculture for their livelihood and the farmers would be expected to buy other farm inputs like fertilizer, stones to conserve their farm land. In the study area, majority of the farmer's (79\%) use stone bunds as conservation methods and adopting that conservation method is expensive instead farmers rather divert their money into expensive wedding. This would subsequently decrease production as well as productivity and eventually lead to insufficient food to feed the family and hence lead to hunger.

Education of the household had a coefficient of 0.37 and is significant at $5 \%$, which means a unit increase in education would decrease poverty by 1.055 . From the study, about $72 \%$ of the household had no access to formal education. This implies that as more people are educated in the study area, they will be able to adopt the modern methods of farming by using improve seeds, fertilizer and mechanized farming and abandon their indigenous farming method to increase food production in the district and be able to read on labels of chemicals such as fungicides, insecticides and pesticides and their recommended formulation to avoid contaminating the ground water, soil pollution, environmental pollution and hence help improve their marginal living, weak markets, moisture stressed, heavily degraded and less productive lands, rapid depletion in soil fertility which makes them unable to produce on a large scale to meet the demand of the larger market throughout the year. Hence if farmers are given the required education, poverty level in the district would decrease. This confirms to a study done by Sikander \& Ahmed [12] who reported that lack of education is the main cause of poverty in Punjab.

The member of farmer based organization had a coefficient of 0.61 and is significant at one percent, which means a unit increase in farmer based organization would reduce poverty 
by 0.351 . This implies that as farmers in this study area engage in farmer based association, they would be able to share their experiences in farming and also advice themselves on some of the best farming practices and best conservation methods to adopt to control erosion for maximum output.

Labor employed by farmers had a coefficient of 0.201 and is significant at $1 \%$, which means a unit increase in labor would reduce poverty by 0.8054 . Adoptionof soil conservation methods was labor intensive in the study area especially in the adoption of stone bunds. More people were needed in the study area by the farmers to help in constructing the conservation methods and the most labor employed was family labor. This implies that as more labor is being employed by farmers on their farm land for crop production and preventing erosion, those farmers would tend to have higher output than those who do not and this could indirectly decrease poverty and hunger among their household. This contradicts to the findings of Farida \& Fariya [11], that labor is an important determinant in increasing poverty among tomato farmers in Talensi Nabdam District of Ghana.

Access to credit had a coefficient of 0.050 and is significant at $1 \%$, which means a unit increase in credit access would reduce poverty by 1.624.Adoption of soil conservation methods is capital intensive especially the favorite conservation methods adopted by the farmers in the study area which was stone bunds. This implies that, as farmers in the study area had access to credit, they would be able to increase their farm size, buy stones, employed more labor, buy improved seeds, practice mechanized farming, fertilizers, pesticides and this could eventually increase production as well as farmers income to be able to repay any loan collected and qualify for another. As production is being increased, poverty would reduce drastically and avoid hunger in the district. This confirms to a study by Khalid et al. 2005 who reported that the availability of loans helps the poor to come out of poverty.

Extension contact had a coefficient of 0.030 and is significant at $5 \%$, which means a unit increase in extension contact would reduce poverty by 1.347 . This implies that those farmers who have access to extension contact would be able to increase their knowledge in the adoption of the conservation methods in other to have higher yield and consequently reduce poverty and hunger in the community.

Access to training had a coefficient of 0.031 and is significant at one percent, which means a unit increase in training of the conservation methods would reduce poverty by 0.912 . This implies that farmers would have a practical training as well as experience in adopting the conservation methods as a way of reducing land degradation and increasing yield.

Awareness of soil conservation methods had a coefficient of 0.202 and is significant at $10 \%$, which means a unit increase in awareness of the conservation methods, would reduce poverty by 0.306 . From the study, about $86 \%$ of the farmers were aware of the conservation methods. This implies that, farmers who were aware of the conservation methods would be able to adopt the most effective conservation methods on their farmland and directly increase output and also increase their farm income as a way of reducing poverty and hunger.

\section{Comparison of output of adopters and non-adopters of the conservation technologies}

Table 2: Estimate of independent-samples t-test of millet farmers that are adopters and non-adopters of the conservation methods.

\begin{tabular}{|c|c|c|c|}
\hline Dependent variable & Mean & $\begin{array}{l}\text { Standard } \\
\text { deviation }\end{array}$ & Sig (2-tailed) \\
\hline $\begin{array}{l}\text { Output of adopters of } \\
\text { stone bunds }\end{array}$ & 320.25 & 209.236 & 0.01 \\
\hline $\begin{array}{l}\text { Output of non- } \\
\text { adopters of stone } \\
\text { bunds }\end{array}$ & 260.1 & 101.816 & 0.03 \\
\hline $\begin{array}{l}\text { Output of adopters of } \\
\text { earth bunds }\end{array}$ & 270.23 & 204.666 & 0.01 \\
\hline $\begin{array}{l}\text { Output of non- } \\
\text { adopters of earth } \\
\text { bunds }\end{array}$ & 300.61 & 222.023 & 0.02 \\
\hline $\begin{array}{l}\text { Output of adopters of } \\
\text { vertiver grass }\end{array}$ & 270.4 & 215.743 & 0 \\
\hline $\begin{array}{l}\text { Output of non- } \\
\text { adopters vertiver } \\
\text { grass }\end{array}$ & 311.68 & 265.006 & 0.003 \\
\hline $\begin{array}{c}\text { Output of adopters of } \\
\text { manure }\end{array}$ & 340.62 & 218.899 & 0 \\
\hline $\begin{array}{l}\text { Output of non- } \\
\text { adopters manure }\end{array}$ & 301.97 & 270.032 & 0.01 \\
\hline
\end{tabular}

Table 2 below shows the variables used in the independentsamples t-test. The test (dependent) variables were outputs of rice farmers that were adopters and non-adopters of the conservation methods which were in kilogram. The group (independent) variables in this study were defined as follows: stone bunds-This was coded as a dichotomous variable with 1 if a farmer adopts stone bunds and 0 if otherwise, 1 if a farmers adopts earth bunds and 0 if otherwise, 1 if a farmer adopts ver tiver grass and 0 if otherwise, 1 if a farmer adopts manure and 0 if otherwise.

\section{Results of independent-samples t-test}

From table 2 below, the results of the independent-samples t-test shows that, the group means 320.25 for output of adopters of stone bunds and 260.10 for output of non-adopters of stone bunds were significantly different because the value in the sig ( 2 tailed) row 0.01 and 0.03 were less than 0.05 . This implies that, those farmers who adopted stone bunds had high output of rice than those who do not adopt stonebunds. This confirms to the findings of Byiringiro \& Reardon [13] that used farm-level data in Rwanda and found that farms with greater investment in soil conservation had much greater land productivity than farms without such investment.

The group means 270.23 for output of adopters of earth bundsand 300.61 for output of non-adopters of earth bunds 
were significantly different because the value in the sig ( 2 tailed) row 0.02 and 0.00 were less than 0.05 . This implies that, those farmers who adopted earth bunds had low output of rice than those who did not adopt earth bunds. This confirms to a study by Kassie \& Holden [14], who found that physical conservation measures (specifically fanyajuu) resulted in lower yield in a highrainfall area of Ethiopian Highlands compared to plots without conservation measures.

The group means 270.40 for output of adopters of vertiver grass and 311.68 for output of non-adopters of vertiver grass were significantly different because the value in the sig ( 2 tailed) row 0.00 and 0.003 were less than 0.05 . This implies that, those farmers who adopted vertiver grass had low output of rice than those who do not adopt vertiver grass. This contradicts with a study done by Kaliba \& Rabele [15] in Lesotho who found a statistically significant positive association between wheat yield and short and long term soil conservation measures.

The group means340.62 for output of adopters of manure and 301.97 for output of non-adopters of manure were significantly different because the value in the sig ( 2 tailed) row 0.00 and 0.01 were less than 0.05 . This implies that, those farmers who adopted manure had higher output of rice than those who do not adopt manure. This confirms to a study done by Fariya [16] who reported that adopters of manure had higher output of groundnut and millet than non-adopters.

\section{Conclusion}

The study reveals that, adopters of stone bunds and manure had higher output of rice than non-adopters whiles adopters of earth bunds and vertiver grass had low output of rice than non-adopters. The study concluded that all the variables have negative and significant effect on poverty and hunger whiles age; gender and marital status have positive and significant effect on poverty and hunger and household size was not significant [17].

\section{Policy Recommendations}

Based on the findings from the study,

A. Is a need for extension education support the provision of knowledge and skills to help in alleviating poverty in the district.

B. Government policies should be directed towards addressing the needs of farmers by making credit available to them.

\section{Acknowledgement}

The authors wish to thank the staff of Ministry of Food and Agriculture, Bolgatanga and to all those who contributed to the success of this research.

\section{References}

1. Nelson W, Agbey SND (2005) Linkages between poverty and climate change adaptation for livelihood of the poor in Ghana. Technical Paper, pp. 452.

2. ISSER (2004) The State of Ghanaian Economy in 2003. University of Ghana, Accra, Ghana, p. 45.

3. Carney D (1999) Formal Farmers' Organizations in the Agricultural Technology System: Current Roles and Future Challenges. Natural Resources Perspective, No. 4, ODI, London, England.

4. World Bank (1999) World Development Report. Consultation with the Poor in Nigeria: "Voice of the poor". Country Synthesis Report, Nigeria, p. 1-30.

5. Kankwenda M (2000) Poverty Eradication; Where Stands Africa, UNDP, London, England.

6. Asamoah KK (2010) The Contributions of International Development Agencies to Rural Poverty Reduction in Ghana: A Case Study of the International Fund for Agricultural Development (IFAD) and SmallHolder Farming in the Sekyere-West District s, Ashanti Region, Knust.

7. Hengsdijk H, Meijerink GW, Mosugu ME (2005) "Modelling the Effect of Three Soil and Water Conservation Practices in Tigray, Ethiopia". Agriculture, Ecosystems and Environment 105(1-2): 29-40.

8. Shively GE (1998a) "Modeling Impacts of Soil Conservation on Productivity and Yield Variability: Evidence from a Heteroskedastic Switching Regression. Paper presented atthe American Agricultural Economics Association Annual Meeting, Salt Lake City, Utah.

9. Fariya A, Victor $O$ (2014) Adoption of Soil Conservation Technologies among Farmers in the Upper East Region of Ghana. IJASRT in EESS 4(2): 61-67.

10. Adesina AA, Zinnah M (1993) Technology characteristics, farmers' perceptions and adoption decisions: A Tobit model application in Sierra Leone. Agricultural Economics 9(4): 297-311.

11. Fariya A, Fariya A (2015) Effects of Soil Conservation on the Yield of Crops among Farmers in Upper East Region of Ghana. Acad Res J Agri Sci Res 3(5): 86-91.

12. Sikander MU, Ahmed M (2008) Household Determinants of Poverty in Punjab: A Logistic Regression Analysis of Mics 2003-04 Data Set $8^{\text {th }}$ Global Conference on Business and, Italy.

13. Byiringiro F, Reardon T (1996) "Farm Productivity in Rwanda: Effects of Farm Size, Erosion, and Soil Conservation Investments". Agricultural Economics 15(2): 127-136.

14. Kassie M, Holden ST (2005) "Parametric and Non-parametric Estimation of Soil Conservation Adoption Impact on Yield and Yield Risk." Paper presented at the $6^{\text {th }}$ International Conference of the European Society for Ecological Economics, Lisbon, Portugal.

15. Kaliba ARM Rabele T (2004) "Impact of Adopting Soil Conservation Practices on Wheat Yield in Lesotho." In Bationo A (Ed.), Managing Nutrient Cycles to Sustain Soil Fertility in Sub-Saharan Africa, International Center for Tropical Agriculture (CIAT), Tropical Soil Biology and Fertility Institute, Columbia, USA.

16. Farida A (2015) Determinants of Poverty among Tomato Farmers in Upper East Region of Ghana. Acad Res J Agri Sci Res 3(5): 92-95.

17. International Fund for Agricultural Development (2003) "Achieving the Millennium Development Goals by Enabling the Rural Poor to Overcome their Poverty". IFAD Discussion Paper, IFAD, Rome, Italy, p. l-37. 
This work is licensed under Creative Commons Attribution 4.0 License DOI: 10.19080/ARTOAJ.2017.03.555612
Your next submission with Juniper Publishers will reach you the below assets

- Quality Editorial service

- Swift Peer Review

- Reprints availability

- E-prints Service

- Manuscript Podcast for convenient understanding

- Global attainment for your research

- Manuscript accessibility in different formats (Pdf, E-pub, Full Text, audio)

- Unceasing customer service

Track the below URL for one-step submission https://juniperpublishers.com/online-submission.php 